\title{
A Bridge Over Troubled Water. The Adaptation of Physical Activities to People with Intellectual Disabilities
}

\author{
Pere Lavega-Burgués* \\ National Institute of Physical Education of Catalonia, Universitat de Lleida, Spain
}

Submission: January 27, 2019; Published: May 23, 2019

*Corresponding author: Pere Lavega-Burgués, National Institute of Physical Education of Catalonia, Universitat de Lleida, Spain

\section{Opinion}

In 1959 years, Pierre Parlebas, Emeritus Professor at the Sorbonne University of Paris in the field of sociology of sport, and Dr. Honoris Causa (University of Lleida, Spain, University of Campinas, Brazil), published his first scientific contribution. Although he is not well known in Anglo-Saxon culture, he could be considered the Darwin, the Einstein, the Freud or the Copernicus of Physical Education proposing a paradigm change. His encyclopaedic training: University degree in physical education, sport, sociology, linguistics, mathematics, allows him to create a new discipline: the science of motor action or motor praxeology.

This discipline provides relevant, original and applied knowledge for the professional of physical activity and sport. From an epistemological point of view, this discipline elevates any physical activity, game or sport to the category of noble research object. Motor action science indicates that any game is born from a democratic contract agreed by the players when they decide to play and respect the rules. The rules establish rights and prohibitions that all participants must respect democratically. The rules stipulate the limits of intervention and contain the internal logic or identity card of any sporting game. Parlebas proposes a systemic conception for understanding the internal relations that are triggered in any game by using a structural approach (taking the Kant's, Saussure`s or Lewin's concept of structure, understood as a system of relationships).

The message is very clear; games or sports cannot be classified according to a hierarchical criterion that establishes activities of first or second category. Each game is the source of a unique set of relationships and the interest of its application will depend on the educational, recreational or competitive objectives established by the intervention program. Motor praxeology shows that underneath an apparent disorder that reigns in the intervention of some players when they play together, there is a deep order corresponding to the structure of the internal logic of that activity. In order to reveal this deep order, the motor action science provides different universal or operative models. As an example, the motor communication network reveals that in sport the motor communication network of duels prevails (two players; one against one: in tennis, badminton, judo, boxing... or two teams, one against one: football, soccer, basketball, handball, baseball, rugby...). However, in other types of games, the relational structure is very different, and allow players to: change opponents (chase games), change teams or even be partners and opponents at the same time (ambivalent or paradoxical games).

Proposing a plural adapted physical education to people with intellectual disabilities should involve an adaptation of all possible ways of motor communication network. However, often the educational, recreational and competitive proposals are basically aimed at adapting situations corresponding to sports. Thus, the adapted imitation of the model of the Olympic Games is observed, through the organization of actions such as the special Olympics in Spain.

One of the criteria proposed for the science of motor action to classify physical activities is the type of motor relationship established by the players. From this point of view distinguishes psychomotor games (such as swimming or short athletic races, and many sporting games) from sociometer games of cooperation (dances, relays, and many sporting games), opposition (with one or more opponents: judo, tennis, fights and many sporting games), cooperation-opposition (basketball, football and many sporting games).

The scientific evidences show that the effects of the different type of games or sports is different on the physiological, relational, emotional and decisional players experience. For this reason, it seems reasonable that in the context of the second European congress of adapted physical activity in intellectual disability (2008), we carried out an inclusive experience using 
cooperative socio-motor games. The impact of these games on the relational well-being of the participants was very positive, unleashing real examples of solidarity, empathy and group pact between people with and without intellectual disabilities [1].

Motor praxeology is a solid scientific discipline, a bridge to intervene and investigate in troubled water. The lack of order, of applied knowledge does not help to find the right course to propose personalized interventions on people with intellectual disabilities. The trophy, victory is not the end, but an element that testifies to the success of the participants. However, success should lie in learning to interpret the motor conduct of the participants. The body takes centre stage to the word and is filled with messages loaded with meaning.

The adaptation of any game to people with disabilities should be aimed at presenting the rules in an appropriate way to generate optimal flowing experiences [2]. This is the challenge of our last funded European project (Erasmus+ program): Together: The promotion of inclusive intercultural dialogue through traditional sports and games (TSG). Three centres for people with intellectual disabilities in Spain, Italy and France, together with the National Institute of Physical Education of Catalonia (INEFC, University of Lleida) and the European Association of Traditional Games and Sports (ETSGA), will try to show tools to adapt the TSGs and research their effects on participants. Motor praxeology will be used as a bridge over this troubled water.

Therefore, it is not by chance that few months ago a new Parlebas' book was published in Spanish [3], which gathers some of his main first scientific contributions. During the public presentation of this book, Parlebas presented a conference entitled The drunked boat, remembering an article published a few years ago [4].

\section{References}

1. Lavega P, Planas A, Ruiz P (2014) Cooperative games and inclusion in physical education. International Journal of Medicine and Science of Physical Activity and Sport 14(53): 37-51.

2. Csikszentmihalyi M (2014) Flow and the foundations of positive psychology. Springer, Dordrecht, Netherlands.

3. Parlebas P (2018) La aventura praxiológica. Ciencia, acción y educación física [The praxiological adventure. Science, action and physical Education]. Málaga: Instituto Andaluz del Deporte, Spain.

4. Parlebas $P$ (2014) Le bateau ivre [The drunken boat]. In: V Lemay V, Darbellay F (eds). L'interdisciplinarité racontée. Chercher hors frontières, vivre l'interculturalité [The interdisciplinarity narrated. Searching across borders, living interculturality], Bern: Peter Lang, Switzerland p. 57-68.

\section{Your next submission with Juniper Publishers will reach you the below assets}

- Quality Editorial service

- Swift Peer Review

- Reprints availability

- E-prints Service

- Manuscript Podcast for convenient understanding

- Global attainment for your research

- Manuscript accessibility in different formats ( Pdf, E-pub, Full Text, Audio)

- Unceasing customer service

Track the below URL for one-step submission https://juniperpublishers.com/online-submission.php 